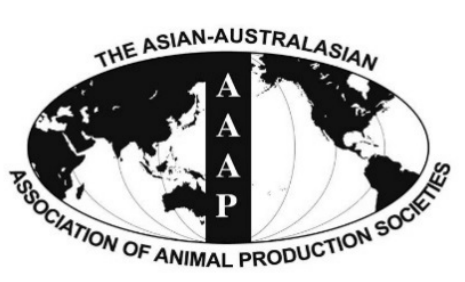

Open Access

Asian Australas. J. Anim. Sci.

Vol. 29, No. 8 : 1129-1135 August 2016

http://dx.doi.org/10.5713/ajas.15.0737

www.ajas.info

pISSN 1011-2367 elSSN 1976-5517

\title{
Effects of Nitrogen Application Rate on the Yields, Nutritive Value and Silage Fermentation Quality of Whole-crop Wheat
}

\author{
C. J. Li ${ }^{1}$, Z. H. Xu' ${ }^{1}$, Z. X. Dong ${ }^{1}$, S. L. Shi ${ }^{2}$, and J. G. Zhang ${ }^{1,2, *}$ \\ ${ }^{1}$ Department of Grassland Science, South China Agricultural University, Guangzhou 510642, China
}

\begin{abstract}
Whole-crop wheat (Triticum aestivum L.) as forage has been extensively used in the world. In this study, the effects of $\mathrm{N}$ application rates on the yields, nutritive value and silage quality were investigated. The $\mathrm{N}$ application rates were $0,75,150,225$, and $300 \mathrm{~kg} / \mathrm{ha}$. The research results indicated that the dry matter yield of whole-crop wheat increased significantly with increasing $\mathrm{N}$ rate up to $150 \mathrm{~kg} / \mathrm{ha}$, and then leveled off. The crude protein content and in vitro dry matter digestibility of whole-crop wheat increased significantly with increasing $\mathrm{N}$ up to $225 \mathrm{~kg} / \mathrm{ha}$, while they no longer increased at N $300 \mathrm{~kg} / \mathrm{ha}$. On the contrary, the content of various fibers tended to decrease with the increase of $\mathrm{N}$ application. The content of lactic acid, acetic acid and propionic acid in silages increased with the increase of $\mathrm{N}$ rate $(\mathrm{p}<0.05)$. The ammonia-N content of silages with higher $\mathrm{N}$ application rates $(\geq 225 \mathrm{~kg} / \mathrm{ha})$ was significantly higher than that with lower $\mathrm{N}$ application rates $(\leq 150 \mathrm{~kg} / \mathrm{ha})$. Whole-crop wheat applied with high levels of $\mathrm{N}$ accumulated more nitrate$\mathrm{N}$. In conclusion, taking account of yields, nutritive value, silage quality and safety, the optimum $\mathrm{N}$ application to whole-crop wheat should be about $150 \mathrm{~kg} / \mathrm{ha}$ at the present experiment conditions. (Key Words: Nitrogen Application, Nutritive Value, Silage, Wholecrop Wheat, Yield)
\end{abstract}

\section{INTRODUCTION}

The demand for animal products in developing countries is quickly growing with the improvement of living standards and consumption structure changes. However, the development of animal husbandry is usually restricted by an insufficiency of forage supply. Therefore, developing and utilizing new forage resources will become very important. Wheat (Triticum aestivum L.) is one of the important grain crops in China and other countries. Although it has been used as forage for a long time abroad, it is seldom used in China due to an emphasis on producing grains for food. However, it has become one of the common cereal crops for ensiling in many parts of the world. For example, wheat is one of the important silage crops in Turkey (Filya, 2003), and in Israel wheat silages are the

\footnotetext{
* Corresponding Author: J. G. Zhang. Tel: +86-20-38604789, Fax: +86-20-38604789, E-mail: zhangjg@scau.edu.cn

2 Pratacultural College, Gansu Agricultural University, Lanzhou 730070, China.

Submitted Sept. 3, 2015; Revised Nov. 26, 2015; Accepted Dec. 8, 2015
}

major roughage for high-producing dairy cows (Weinberg et al., 2009).

Whole-crop wheat has good dry matter (DM) yield, high DM content and a relatively high content of watersoluble carbohydrates (WSC), which improve the ensiling process (Khorasani et al., 1997). The wheat silage also has a similar chemical composition and nutritive value to the silages of Italian ryegrass (Lolium multiflorum L.) and barley (Hordeum vulgare L.) (Succi et al., 1993; Crovetto et al., 1996). Ashbell and Sklan (1985) found that the nutritive value of wheat silage was higher by $10 \%$ to $20 \%$ than wheat hay, and equal to corn (Zea mays L.) silage, but the crude protein $(\mathrm{CP})$ content in whole-crop wheat is relatively high. Moreover, an in situ degradability trial showed that wheat silage, harvested at the milk-dough stage, had a higher rumen degradability of DM and neutral detergent fiber (NDF) than other winter cereals, although it was lower than Italian ryegrass. The research of Succi et al. (1993) showed that the whole-crop wheat silage at the dough stage had a high net energy content for lactation. The high nutritive value suggests that wheat silage could be successfully used 
in dairy cow rations (Ben-Ghedalia et al., 1995). Morrison (1979) reported that wheat is also relatively rich in hemicelluloses which can be partially hydrolyzed to pentose sugars during ensiling and they may be utilized to generate more acetic acid, which inhibit yeast and mold growth and improve the aerobic stability of silage. In addition, the feed intake of cows and beefs could be increased by adding some whole-crop wheat silage to fodder based on pasture (Phipps et al., 1995).

The silage fermentation quality of wheat is affected by many factors. Among them, the harvest time is one of the most important. In addition, fertilization management affects the silage fermentation, as well as the yield and nutritive value. It is well known that the application of $\mathrm{N}$ fertilizers to wheat often results in considerable increases in yields of grain and straw. However, this is not a linear relationship and there is an economic optimum application offsetting incremental yield increase against the cost of additional $\mathrm{N}$ inputs (Foulkes et al., 1998). The research suggests that the optimal synthetic $\mathrm{N}$ application rates to grain wheat in China should be in the range from 110 to 150 $\mathrm{kg} / \mathrm{ha}$ (Chai et al., 2013). There is much research on $\mathrm{N}$ application to wheat for grains rather than for forage. Ghanbari-Bonjan and Lee (2002) studied the effect of $\mathrm{N}$ application up to $150 \mathrm{~kg} / \mathrm{ha}$ on the yield and CP content of whole-crop wheat, which were increased by increased $\mathrm{N}$ application. However, the effect on forage wheat by a higher $\mathrm{N}$ applying rate is not clear yet. In this study, the effects of $\mathrm{N}$ application rate up to $300 \mathrm{~kg} / \mathrm{ha}$ on the yield, nutritive value and silage fermentation quality of wholecrop wheat were studied, in order to provide more information for the production and ensiling of whole-crop wheat.

\section{MATERIALS AND METHODS}

\section{Experimental site}

The experiment was carried out in an experimental field of South China Agricultural University (Guangzhou, China),

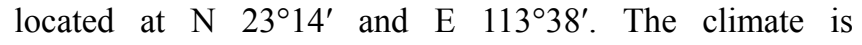
subtropical monsoon with an annual average temperature of $21.6^{\circ} \mathrm{C}$. The hottest weather is in July with a monthly average temperature of $29.4^{\circ} \mathrm{C}$, while the coldest weather is in January with a monthly average temperature $13.3^{\circ} \mathrm{C}$. The annual average rainfall and sunshine hours are $1,967.8 \mathrm{~mm}$ and $1,707.2 \mathrm{~h}$, respectively.

The soil fertility of experimental field was as follows: organic matter $10.2 \mathrm{~g} / \mathrm{kg}$, total nitrogen $0.85 \mathrm{~g} / \mathrm{kg}$, total phosphorus $0.62 \mathrm{~g} / \mathrm{kg}$, total potassium $14.82 \mathrm{~g} / \mathrm{kg}$, rapidly available nitrogen $32.35 \mathrm{~g} / \mathrm{kg}$, rapidly available phosphorus $76.19 \mathrm{~g} / \mathrm{kg}$, rapidly available potassium $85.42 \mathrm{~g} / \mathrm{kg}$, and $\mathrm{pH}$ 5.40 .

\section{Wheat planting and management}

Five $\mathrm{N}$ application rates of $0,75,150,225$, and 300 $\mathrm{kg} / \mathrm{ha}$ were designed, and applied at a ratio of 6 to 4 as base fertilizer to topdressing at jointing stage. Each plot was 3.0 $\mathrm{m} \times 4.0 \mathrm{~m}$ and each treatment was in triplicate. Wheat, a variety of Shimai 01, was sown on December 25, 2013, and the seeding rate was $260 \mathrm{~kg} / \mathrm{ha}$. Before sowing, $\mathrm{P}_{2} \mathrm{O}_{5} 45.0$ $\mathrm{kg} / \mathrm{ha}$ and $\mathrm{K}_{2} \mathrm{O} 60.0 \mathrm{~kg} / \mathrm{ha}$ were applied to all plots.

\section{Field investigation and sampling}

Plant height and tiller numbers were investigated through randomly measuring 10 plants in each plot. The yield at dough stage was determined by harvesting the whole crop from a quadrant of $1.0 \mathrm{~m} \times 1.0 \mathrm{~m}$ in triplicates and calculating the average. The fresh samples were taken for microbial analyses and silage making. Dried materials were ground by a hammer mill with $0.45-\mathrm{mm}$ sieve for chemical analyses.

\section{Silage making}

Fresh wheat materials were chopped into 2 to $3 \mathrm{~cm}$ lengths by a forage chopper. After thorough mixing, $300 \mathrm{~g}$ of fresh materials was immediately packed into a plastic film bag $(30 \mathrm{~cm} \times 40 \mathrm{~cm}$, Mingkang Packing Co. Ltd., Zhongshan, China) in triplicates, degassed and sealed using a vacuum sealer (SINBO Vacuum Sealer, Hong Tai Home Electrical Appliance Co. Ltd., Hong Kong, China). Thereafter, the bags were maintained at dark place for $60 \mathrm{~d}$ at the ambient temperature.

\section{Microbial and chemical analyses}

Twenty grams of fresh sample were taken, mixed with $80 \mathrm{~mL}$ of distilled water in a polyethylene plastic bag, and stored in a refrigerator at $4{ }^{\circ} \mathrm{C}$ overnight. The material was then filtered through filter paper. The water extract was used to determine the $\mathrm{pH}$ value with a glass electrode $\mathrm{pH}$ meter (PHS-3C, CSDIHO Co., Ltd, Shanghai, China). Ten grams of fresh material were shaken well with $90 \mathrm{~mL}$ of sterilized saline solution $(8.50 \mathrm{~g} / \mathrm{L} \mathrm{NaCl})$, and serial dilutions $\left(10^{-1}\right.$ to $\left.10^{-5}\right)$ were made in sterile saline solution. Lactic acid bacteria (LAB) were counted on de Man, Rogosa and Sharp medium agar (Difco Laboratories, Detroit, MI, USA) after incubation under anaerobic conditions at $37^{\circ} \mathrm{C}$ for 3 days. Aerobic bacteria were counted on nutrient agar (Nissui-Seiyaku Ltd, Tokyo, Japan), while yeasts and molds were counted on potato dextrose agar (Nissui-seiyaku Ltd., Japan) acidified with sterilized tartaric acid solution to $\mathrm{pH}$ of 3.5. The agar plates were incubated at $37^{\circ} \mathrm{C}$ for 3 days.

The DM content of wheat before and after ensiling was determined after drying at $70^{\circ} \mathrm{C}$ for 48 hours in an oven with forced air circulation. Crude fiber, CP, and ether 
extracts were analyzed according to AOAC (1990) methods (962.09, 984.13, and 920.39). Crude ash content was determined by burning in a muffle furnace at $550^{\circ} \mathrm{C}$ for $5 \mathrm{~h}$. WSC content was determined by using the anthrone method (Murphy, 1958). The buffering capacity of whole-plant wheat was determined, as described by Playne and McDonald (1966). NDF and acid detergent fiber (ADF) were determined according to Van Soest et al. (1991). In vitro dry matter digestibility (IVDMD) was determined by two-stage technique according to the method of Tilley and Terry (1963). Nitrate-N $\left(\mathrm{NO}_{3}-\mathrm{N}\right)$ was determined by absorption photometric method (Lv et al., 2004). Concentration of ammonia-N $\left(\mathrm{NH}_{3}-\mathrm{N}\right)$ was analyzed by using the indophenols blue method (Novozamsky et al., 1974). The organic acid contents were analyzed by HPLC (column: Sodex RS Pak KC-811, Showa Denko KK, Kawasaki, Japan; detector: DAD, $210 \mathrm{~nm}$, SPD-20A, Shimadzu Co, Ltd, Kyoto, Japan; eluent: $3 \mathrm{mmol} / \mathrm{L} \mathrm{HClO} 4$, $1.0 \mathrm{~mL} / \mathrm{min}$; temperature: $60^{\circ} \mathrm{C}$ ).

Aerobic stability was studied by monitoring the $\mathrm{pH}$ value change of silages that was put in insulated polystyrene foam boxes at ambient temperature and covering with gauze to allow air to enter. The $\mathrm{pH}$ value of silages was measured at 48, 96, 144, and 192 h, respectively.

\section{Relative feed value}

Relative feed value (RFV) was developed by the Hay Marketing Task Force of the American Forage and Grassland Council (Rohweder et al., 1978). RFV is calculated from estimation of ADF (\% DM) and NDF (\% $\mathrm{DM})$. The formula for calculating RFV is:

$$
\operatorname{RFV}(\%)=93 \times(88.9-0.779 \times \mathrm{ADF}) / \mathrm{NDF}
$$

\section{Data analysis}

The data were analyzed by one-way analysis of variance to evaluate the effects of $\mathrm{N}$ application rates on plant height,
Table 1. Effects of $\mathrm{N}$ application rates on height, effective tiller number and yield of wheat

\begin{tabular}{lcccccc}
\hline \multirow{2}{*}{ Items } & \multicolumn{5}{c}{$\mathrm{N}$ application rates $(\mathrm{kg} / \mathrm{ha})$} & \multirow{2}{*}{ SEM } \\
\cline { 2 - 6 } & 0 & 75 & 150 & 225 & 300 & \\
\hline Height $(\mathrm{cm})$ & $66.54^{\mathrm{c}}$ & $70.12^{\mathrm{b}}$ & $70.31^{\mathrm{b}}$ & $71.98^{\mathrm{ab}}$ & $72.79^{\mathrm{a}}$ & 0.63 \\
Tiller number & $1.17^{\mathrm{d}}$ & $1.40^{\mathrm{cd}}$ & $2.00^{\mathrm{bc}}$ & $2.62^{\mathrm{ab}}$ & $3.20^{\mathrm{a}}$ & 0.22 \\
DM yield (t/ha) & $3.98^{\mathrm{c}}$ & $5.30^{\mathrm{b}}$ & $8.78^{\mathrm{a}}$ & $8.70^{\mathrm{a}}$ & $8.67^{\mathrm{a}}$ & 0.55 \\
CP yield (t/ha) & $0.16^{\mathrm{d}}$ & $0.36^{\mathrm{c}}$ & $0.67^{\mathrm{b}}$ & $0.73^{\mathrm{a}}$ & $0.73^{\mathrm{a}}$ & 0.06 \\
\hline
\end{tabular}

SEM, standard error of the mean; DM, dry matter; CP, crude protein. Values within a row with different superscripts in lowercase letters differ significantly from each other at $\mathrm{p}<0.05$.

tiller number, yields, and the chemical and microbial compositions of wheat prior to ensiling and fermentation quality after ensiling. The means of the data were then compared for significance by Duncan's multiple range method. All statistical procedures were performed by using the Statistical Packages for the Social Sciences (SPSS 17.0 for Windows; SPSS Inc., Chicago, IL, USA).

\section{RESULTS}

\section{Effects on the plant height, yield and relative feed value}

The height of wheat increased with the increase of $\mathrm{N}$ application rate, and reached $72.79 \mathrm{~cm}$ at $\mathrm{N} 300 \mathrm{~kg} / \mathrm{ha}$, which was significantly higher than that of the other $\mathrm{N}$ rates except $225 \mathrm{~kg} / \mathrm{ha}(\mathrm{p}<0.05)$ (Table 1). The tiller number also increased with the $\mathrm{N}$ increase. The DM yield increased significantly with the $\mathrm{N}$ application increase from 0 to 150 $\mathrm{kg} / \mathrm{ha}(\mathrm{p}<0.05)$, but it stagnated when the $\mathrm{N}$ application exceeded $150 \mathrm{~kg} / \mathrm{ha}(\mathrm{p}>0.05)$. The CP yield and IVDMD increased significantly with the $\mathrm{N}$ application increase from 0 to $225 \mathrm{~kg} / \mathrm{ha}(\mathrm{p}<0.05)$, but it did not further increase at $\mathrm{N}$ $300 \mathrm{~kg} / \mathrm{ha}$ (Figure 1). The RFV tended to increase with increasing $\mathrm{N}$ application rate, but there were no significant differences among the $\mathrm{N}$ application rates from 75 to 300 $\mathrm{kg} / \mathrm{ha}(\mathrm{p}>0.05)$, they all were significantly higher than that

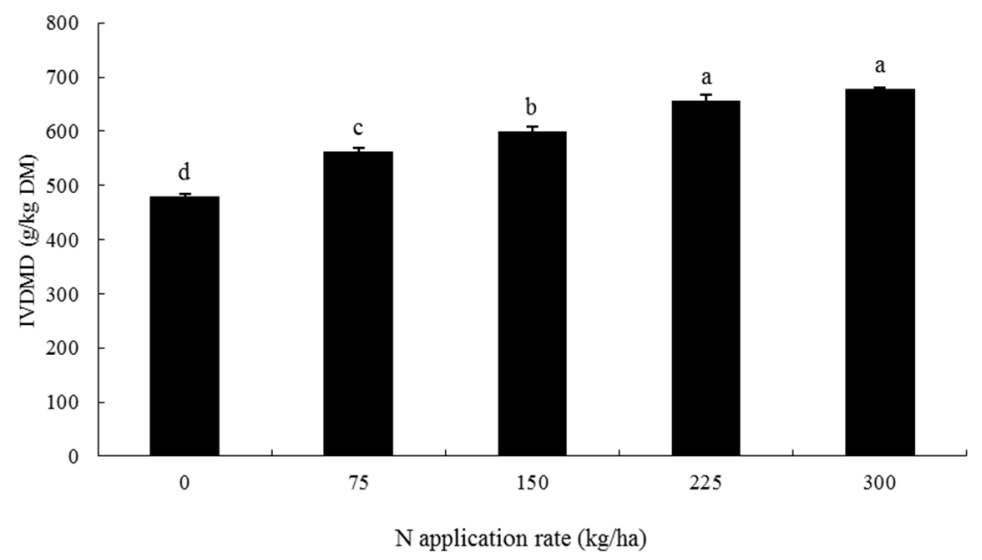

Figure 1. Effects of $\mathrm{N}$ application rate on in vitro dry matter digestibility (IVDMD). Different lowercase letters indicate significant differences at $\mathrm{p}<0.05$ level and error bar shows standard error of data. 
of the control (no N application) $(\mathrm{p}<0.05)$ (Figure 2).

\section{Effects on the composition and epiphytic microorganisms}

The DM content of wheat was the lowest at N $300 \mathrm{~kg} / \mathrm{ha}$ $(\mathrm{p}<0.05)$ (Table 2). The CP and WSC contents increased significantly as the $\mathrm{N}$ application rose from 0 to $225 \mathrm{~kg} / \mathrm{ha}$ $(\mathrm{p}<0.05)$, then they leveled off. The contents of crude fiber, NDF and ADF tended to decrease with increasing $\mathrm{N}$ application rate. Increasing $\mathrm{N}$ application significantly increased the buffering capacity and $\mathrm{NO}_{3}-\mathrm{N}$ content $(\mathrm{p}<0.05)$. Compared with the control, $\mathrm{N}$ application significantly increased the numbers of $\mathrm{LAB}$ and yeasts on whole-crop wheat $(\mathrm{p}<0.05)$, especially for LAB which increased by over 50 to 5,000 times. On the contrary, aerobic bacteria and molds tended to reduce with increasing $\mathrm{N}$ application rate.

\section{Effects on the fermentation quality and aerobic stability of silage}

The contents of lactic acid, acetic acid and propionic acid of silages increased with the increase of $\mathrm{N}$ application. Butyric acid was not detected in any of the silages. The silage at $\mathrm{N} 225 \mathrm{~kg} / \mathrm{ha}$ had the highest $\mathrm{NH}_{3}-\mathrm{N}$ content of all the silages, while there were no significant differences among the silages at $\mathrm{N}$ application from 0 to $150 \mathrm{~kg} / \mathrm{ha}$ $(\mathrm{p}>0.05)$. Although the $\mathrm{NO}_{3}-\mathrm{N}$ content was reduced to some extent by ensiling, the silages at $\mathrm{N} 225$ and $300 \mathrm{~kg} / \mathrm{ha}$ contained $\mathrm{NO}_{3}-\mathrm{N}$ over $0.3 \mathrm{~g} / \mathrm{kg}$. The silages at higher $\mathrm{N}$ application (225 and $300 \mathrm{~kg} / \mathrm{ha}$ ) had longer aerobic stability time than the silages at lower $\mathrm{N}$ application (Table 3).

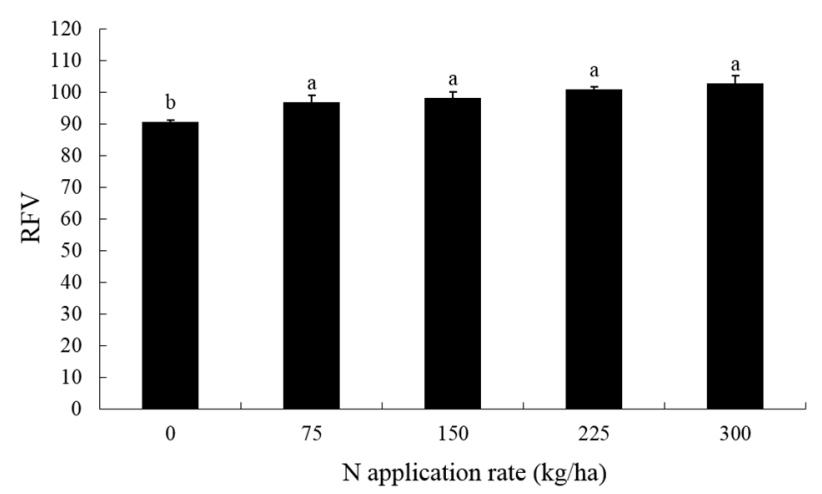

Figure 2. Effects of $\mathrm{N}$ application rate on relative feeding value (RFV). Different lowercase letters indicate significant differences $p<0.05$ level and error bar shows standard error of data.

\section{DISCUSSION}

The DM yield and RFV of forage crops are affected by many factors. Of them, $\mathrm{N}$ application rate is particularly prominent. In the process of ensiling, the fermentation quality of silage is known to be influenced by the chemical composition of crop material, which changes depending on the amount of $\mathrm{N}$ fertilizer used (McDonald et al., 1991). Practices had proved that $\mathrm{N}$ fertilizer could increase forage yield, and affect the content of $\mathrm{N}$ compounds in grass. Increasing $\mathrm{N}$ application rate could increase the $\mathrm{CP}$ and WSC contents, and improve IVDMD of corn silage, meanwhile, reduce the content of ADF (Islam et al., 2012). In this experiment, when $\mathrm{N}$ application rate increased from 0 to $150 \mathrm{~kg} / \mathrm{ha}$, the DM yield of whole-crop wheat increased significantly $(p<0.05)$. While no further significant changes

Table 2. Effects of $\mathrm{N}$ application rate on the chemical compositions and epiphytic microbes of wheat prior to ensiling

\begin{tabular}{|c|c|c|c|c|c|c|}
\hline \multirow{2}{*}{ Items } & \multicolumn{5}{|c|}{$\mathrm{N}$ application rates $(\mathrm{kg} / \mathrm{ha})$} & \multirow{2}{*}{ SEM } \\
\hline & 0 & 75 & 150 & 225 & 300 & \\
\hline Dry matter (g/kg FM) & $441.8^{\mathrm{a}}$ & $429.4^{\mathrm{ab}}$ & $431.6^{\mathrm{a}}$ & $410.4^{\mathrm{b}}$ & $387.3^{\mathrm{c}}$ & 5.34 \\
\hline Crude protein (g/kg DM) & $40.7^{\mathrm{d}}$ & $68.5^{\mathrm{c}}$ & $76.3^{\mathrm{b}}$ & $83.7^{\mathrm{a}}$ & $84.5^{\mathrm{a}}$ & 4.31 \\
\hline Ether extract (g/kg DM) & $19.9^{\mathrm{c}}$ & $29.6^{\mathrm{b}}$ & $34.2^{\mathrm{a}}$ & $34.7^{\mathrm{a}}$ & $33.5^{\mathrm{a}}$ & 1.18 \\
\hline Crude fiber (g/kg DM) & $362.7^{\mathrm{a}}$ & $279.9^{\mathrm{b}}$ & $281.2^{\mathrm{b}}$ & $260.0^{c}$ & $247.8^{\mathrm{c}}$ & 10.96 \\
\hline Crude ash $(\mathrm{g} / \mathrm{kg} \mathrm{DM})$ & 64.2 & 64.6 & 63.1 & 66.1 & 67.6 & 0.9 \\
\hline NFE (g/kg DM) & $432.6^{\mathrm{b}}$ & $478.3^{\mathrm{a}}$ & $471.8^{\mathrm{a}}$ & $485.5^{\mathrm{a}}$ & $492.7^{\mathrm{a}}$ & 6.22 \\
\hline NDF (g/kg DM) & $639.1^{\mathrm{a}}$ & $619.6^{\mathrm{ab}}$ & $612.6^{\mathrm{b}}$ & $607.7^{\mathrm{b}}$ & $598.2^{\mathrm{b}}$ & 4.64 \\
\hline $\mathrm{ADF}(\mathrm{g} / \mathrm{kg} \mathrm{DM})$ & $341.7^{\mathrm{a}}$ & $315.2^{\mathrm{b}}$ & $312.0^{\mathrm{bc}}$ & $295.4^{\mathrm{bc}}$ & $294.5^{\mathrm{c}}$ & 5.13 \\
\hline WSC (g/kg DM) & $78.7^{\mathrm{d}}$ & $83.3^{\mathrm{c}}$ & $88.7^{\mathrm{b}}$ & $93.3^{\mathrm{a}}$ & $93.0^{\mathrm{a}}$ & 1.59 \\
\hline $\mathrm{NO}_{3}-\mathrm{N}(\mathrm{g} / \mathrm{kg} \mathrm{DM})$ & nd & $0.10^{\mathrm{d}}$ & $0.21^{\mathrm{c}}$ & $0.42^{\mathrm{b}}$ & $0.71^{\mathrm{a}}$ & 0.07 \\
\hline $\mathrm{pH}$ & 5.98 & 5.93 & 6.06 & 6.24 & 5.92 & 0.05 \\
\hline Buffering capacity (mEq/kg DM) & $173.2^{\mathrm{d}}$ & $202.5^{\mathrm{cd}}$ & $237.3^{\mathrm{bc}}$ & $277.9^{\mathrm{b}}$ & $363.2^{\mathrm{a}}$ & 16.9 \\
\hline Lactic acid bacteria (lg cfu/g FM) & $3.23^{\mathrm{d}}$ & $5.23^{\mathrm{c}}$ & $5.70^{\mathrm{b}}$ & $6.93^{\mathrm{a}}$ & $5.01^{\mathrm{c}}$ & 0.32 \\
\hline Aerobic bacteria (lg cfu/g FM) & $7.19^{\mathrm{a}}$ & $7.18^{\mathrm{a}}$ & $6.88^{\mathrm{b}}$ & $6.71^{\mathrm{b}}$ & $6.87^{b}$ & 0.26 \\
\hline Yeast (lg cfu/g FM) & $6.38^{\mathrm{b}}$ & $6.84^{\mathrm{a}}$ & $6.79^{\mathrm{a}}$ & $7.00^{\mathrm{a}}$ & $6.98^{\mathrm{a}}$ & 0.19 \\
\hline Mold (lg cfu/g FM) & $4.99^{\mathrm{a}}$ & $4.85^{\mathrm{a}}$ & $4.52^{\mathrm{bc}}$ & $4.36^{\mathrm{c}}$ & $4.76^{\mathrm{ab}}$ & 0.1 \\
\hline
\end{tabular}

SEM, standard error of the mean; DM, dry matter; FM, fresh matter; NFE, nitrogen free extract; NDF, neutral detergent fiber; ADF, acid detergent fiber; WSC, water-soluble carbohydrates; nd, not detected; $\mathrm{mEq}$, milli equivalent; lg, denary logarithm of the numbers; cfu, colony-forming units.

Values within a row with different superscripts in lowercase letter differ significantly from each other at $\mathrm{p}<0.05$. 
Table 3. Effects of $\mathrm{N}$ application rate on the fermentation quality of wheat

\begin{tabular}{|c|c|c|c|c|c|c|}
\hline \multirow{2}{*}{ Items } & \multicolumn{5}{|c|}{$\mathrm{N}$ application rates $(\mathrm{kg} / \mathrm{ha})$} & \multirow{2}{*}{ SEM } \\
\hline & 0 & 75 & 150 & 225 & 300 & \\
\hline$\overline{\mathrm{pH}}$ & $4.40^{\mathrm{b}}$ & $4.39^{\mathrm{bc}}$ & $4.41^{\mathrm{ab}}$ & $4.47^{\mathrm{a}}$ & $4.33^{\mathrm{c}}$ & 0.01 \\
\hline Lactic acid (g/kg DM) & $15.7^{\mathrm{b}}$ & $34.5^{\mathrm{ab}}$ & $34.9^{\mathrm{ab}}$ & $35.7^{\mathrm{ab}}$ & $41.7^{\mathrm{a}}$ & 3.52 \\
\hline Acetic acid (g/kg DM) & $6.1^{\mathrm{b}}$ & $7.3^{\mathrm{ab}}$ & $14.4^{\mathrm{ab}}$ & $17.7^{\mathrm{a}}$ & $18.0^{\mathrm{a}}$ & 1.84 \\
\hline Propionic acid (g/kg DM) & $7.3^{\mathrm{c}}$ & $10.0^{\mathrm{c}}$ & $15.3^{\mathrm{b}}$ & $28.0^{\mathrm{a}}$ & $28.5^{\mathrm{a}}$ & 2.42 \\
\hline Butyric acid (g/kg DM) & nd & nd & nd & nd & nd & \\
\hline $\mathrm{NH}_{3}-\mathrm{N}(\mathrm{g} / \mathrm{kg} \mathrm{TN})$ & $234.6^{\mathrm{bc}}$ & $206.8^{\mathrm{c}}$ & $199.7^{\mathrm{c}}$ & $376.4^{\mathrm{a}}$ & $287.7^{\mathrm{b}}$ & 19.13 \\
\hline $\mathrm{NO}_{3}-\mathrm{N}(\mathrm{g} / \mathrm{kg} \mathrm{DM})$ & $0.00^{\mathrm{d}}$ & $0.08^{\mathrm{cd}}$ & $0.15^{\mathrm{c}}$ & $0.33^{\mathrm{b}}$ & $0.60^{\mathrm{a}}$ & 0.06 \\
\hline Aerobic stability (h) & $96.0^{\mathrm{b}}$ & $96.0^{\mathrm{b}}$ & $96.0^{\mathrm{b}}$ & $144^{\mathrm{a}}$ & $144^{\mathrm{a}}$ & 5.84 \\
\hline
\end{tabular}

$\mathrm{N}$, nitrogen; SEM, standard error of the mean; DM, dry matter; nd, not detected; TN, total nitrogen; $\mathrm{NH}_{3}-\mathrm{N}$, ammonia-N; $\mathrm{NO}_{3}-\mathrm{N}$, nitrate-N.

Values within a row with different superscripts in lowercase letter differ significantly from each other at $\mathrm{p}<0.05$

occurred when $\mathrm{N}$ was over $150 \mathrm{~kg} / \mathrm{ha}$. This meant that the $\mathrm{N}$ return rate fell sharply and the economic benefit was lower when $\mathrm{N}$ application rate exceeded $150 \mathrm{~kg} / \mathrm{ha}$ for whole-crop wheat at the present experimental conditions. As the $\mathrm{N}$ application rate rose, the contents of crude fiber, NDF and ADF decreased, the $\mathrm{CP}$ and WSC contents and RFV increased. This indicated that increased $\mathrm{N}$ application could improve the nutritive value of whole-crop wheat. Therefore, the digestible DM yield at $\mathrm{N} 225 \mathrm{~kg} / \mathrm{ha}$ was higher than that at $\mathrm{N} 150 \mathrm{~kg} / \mathrm{ha}$ (Figure 3). However, excessive $\mathrm{N}$ application resulted in more $\mathrm{NO}_{3}-\mathrm{N}$ accumulation in wholecrop wheat (Figure 2), which would be harmful to animals. These results indicated $\mathrm{N}$ should be applied to forage (whole crop) wheat at a similar rate as to grain wheat. Although more $\mathrm{N}$ application might increase the digestible $\mathrm{DM}$ yield, there is a risk of $\mathrm{NO}_{3}-\mathrm{N}$ accumulation. In addition, LAB amount increased significantly with the increased $\mathrm{N}$ application from 0 to $225 \mathrm{~kg} / \mathrm{ha}$. This might be attributed to increased WSC and CP contents at high $\mathrm{N}$ application, which are very important nutrients for the growth of LAB with their strict nutrition requirements.

Ensiling is a fermentation process driven by LAB, which ferment WSC into organic acids (mainly lactic acid) in an anaerobic environment. As a result, $\mathrm{pH}$ is decreased and forage is conserved. Namihira et al. (2011) studied the effect of $\mathrm{N}$ application rate on guinea grass (Panicum maximum Jacq cv. Gatton) and their results showed that the nitrate content was higher in the grass treated with a high $\mathrm{N}$ application rate than that treated with a low $\mathrm{N}$ application rate, with the high levels of nitrate and ammonia perhaps acting as a buffer against $\mathrm{pH}$ change. In the present study, the contents of lactic acid, acetic acid and propionic acid increased with the increase of $\mathrm{N}$ application rate, but the $\mathrm{pH}$ value did not reduce markedly. This might be a result of an increase in buffering capacity.

Aerobic stability of silage is important, because it relates with the safety and quality of the preserved forage upon exposure to air during storage and feeding. Some workers believed that the accumulation of acetic acid was the main reason for the improved aerobic stability of silage. Moon (1983) considered that other acids such as propionic acid and butyric acid could also inhibit the growth of yeasts and molds to improve aerobic stability. Weinberg et al. (2007) studied the effects of $\mathrm{N}$ application rate on the silage quality of safflower (Carthamus tinctorius), the results showed that increasing $\mathrm{N}$ fertilizer could help to increase the acetic acid content and improve aerobic stability of silages. A similar effect of $\mathrm{N}$ fertilization on herbage was found (Keady and O'Kiely, 1996). In the present study, the contents of acetic acid and propionic acid in silages increased with the increased $\mathrm{N}$ application, and the silages were stable for a longer time at N $225 \mathrm{~kg} / \mathrm{ha}$ and $300 \mathrm{~kg} / \mathrm{ha}$. Namihira et al. (2011) reported that grass material fertilized with a high level of urea accumulated a relatively high concentration of $\mathrm{NO}_{3}-\mathrm{N}$, which resulted in better-preserved silage. In general, $\mathrm{NO}_{3}-\mathrm{N}$ in grass material was reduced to nitrite-N or nitric oxide in the early stage of ensiling, and these nitrogenous compounds inhibit clostridial activity in the silo (Spoelstra, 1983). A similar result was also found in this experiment. However, high $\mathrm{NO}_{3}-\mathrm{N}$ accumulation in silage would be toxic for herbivores, due to the formation of methemoglobin. In this study, when the $\mathrm{N}$ application rate was over $225 \mathrm{~kg} / \mathrm{ha}$, the $\mathrm{NO}_{3}-\mathrm{N}$ content of silage was higher

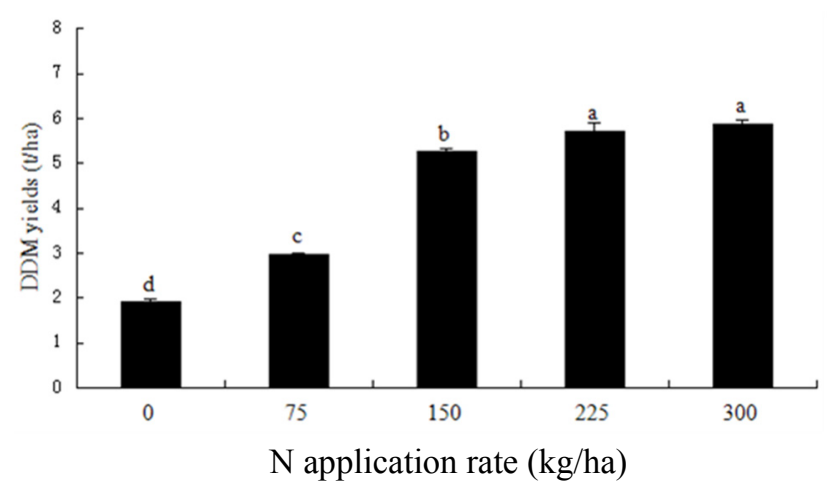

Figure 3. Effects of $\mathrm{N}$ application rates on digestible dry matter (DDM) yield. Different lowercases letter indicate significant differences $\mathrm{p}<0.05$ level and error bar shows standard error of data. 
than $0.25 \mathrm{~g} / \mathrm{kg} \mathrm{DM}$, which is considered as the critical concentration for animals (Sidhu et al., 2011).

In conclusion, the $\mathrm{N}$ application rate not only affected the yields and forage quality, but also affected the silage fermentation of whole-crop wheat. Taking account of yield, nutritive value, silage quality and safety, the optimum $\mathrm{N}$ application to whole-crop wheat should be about $150 \mathrm{~kg} / \mathrm{ha}$ under the present experimental conditions.

\section{CONFLICT OF INTEREST}

We certify that there is no conflict of interest with any financial organization regarding the material discussed in the manuscript.

\section{ACKNOWLEDGMENTS}

This work was supported by National Key Technology R\&D Program for the 12th Five-year Plan (2011BAD17B02), China.

\section{REFERENCES}

AOAC. 1990. Official Methods of Analysis. Association of Official Analytical Chemists, Arlington, VA, USA.

Ashbell, G. and D. Sklan. 1985. Winter wheat for silage: a doublecropping system for use in subtropical climate. Feedstuffs 57:18-19.

Ben-Ghedalia, D., A. Halevi, and J. Miron. 1995. Digestibility by dairy cows of monosaccharide components in diets containing wheat or ryegrass silages. J. Dairy Sci. 78:134-140.

Chai, R. S., Y. F. Niu, L. D. Huang, L. J. Liu, H. Wang, L. S. Wu, and Y. S. Zhang. 2013. Mitigation potential of greenhouse gases under different scenarios of optimal synthetic nitrogen application rate for grain crops in China. Nutr. Cycl. Agroecosyst. 96:15-28.

Crovetto, G. M., A. Tamburini, L. Rapetti, G. Galassiand, and G. Succi. 1996. Nutritive value of Italian ryegrass (Lolium multiflorum Lam.) silage: comparison between double and unique cut.Zoot. Nutr. Anim. 22:59-67.

Filya, I. 2003. Nutritive value of whole crop wheat silage harvested at three stages of maturity. Anim. Feed Sci. Technol. 103:85-95.

Foulkes, M. J., R. Sylvester-Bradley, and R. K. Scott. 1998. Evidence for differences between winter wheat cultivars in acquisition of soil mineral nitrogen and uptake and utilization of applied fertilizer nitrogen. J. Agric. Sci. 130:29-44.

Ghanbari-Bonjar, A. and H. C. Lee. 2002. Intercropped field beans (Vicia faba) and wheat (Triticum aestivum) for whole crop forage: effect of nitrogen on forage yield and quality. J. Agric. Sci. 138:311-315.

Islam, M. R., S. C. Garcia, and A. Horadagoda. 2012. Effects of irrigation and rates and timing of nitrogen fertilizer on dry matter yield, proportions of plant fractions of maize and nutritive value and in vitro gas production characteristics of whole crop maize silage. Anim. Feed Sci. Technnol. 172:125-
135

Keady, T. W. J. and O. P'Kiely. 1996. An evaluation of the effects of rate of nitrogen fertilization of grassland on silage fermentation, in-silo losses, effluent production and aerobic stability. Grass Forage Sci. 51:350-362.

Khorasani, G. R., P. E. Jedel, J. H. Helm, and J. J. Kennelly. 1997. Influence of stage of maturity on yield components and chemical composition of cereal grain silages. Can. J. Anim. Sci. 77:259-267.

Lv, W. X., Y. Ge, J. Z. Wu, and J. Chang. 2004. Study on the method for the determination of nitric nitrogen, ammoniacal nitrogen and total nitrogen in plant. Spectrosc. Spect. Anal. 24:204-206.

McDonald, P., A. R. Henderson, and J. E. Heron. 1991. The Biochemistry of Silage. Chalcombe Publications, Marlow, UK. pp. 9-166.

Moon, N. J. 1983. Inhibition of the growth of acid tolerant yeasts by acetate, lactate and propionate and their synergistic mixtures. J. Appl. Bacteriol. 55:453-460.

Morrison, I. M. 1979. Changes in cell wall components of laboratory silages and the effect of various additives on these changes. J. Agric. Sci. 93:581-586.

Murphy, R. P. 1958. A method for the extraction of plant samples and the determination of total soluble carbohydrates. J. Sci. Food Agric. 9:714-717.

Namihira, T., N. Shinzato, H. Akamine, I. Nakamura, H. Maekawa Y. Kawamoto, and T. Matsui. 2011. The effect of nitrogen fertilization to the sward on guineagrass (Panicum maximum Jacq cv. Gatton) silage fermentation. Asian Australas. J. Anim. Sci. 24:358-363.

Novozamsky, I., E. R. Van, J. C. Van, Schouwenburg, and I. Walinga. 1974. Total nitrogen determination in plant material by means of the indophenol-blue method. Netherland J. Agric. Sci. 22:3-5

Phipps, R. H., J. D. Sutton, and B. A. Jones. 1995. Forage mixtures for dairy cows: the effect on dry-matter intake and milk production of incorporating either fermented or urea treated whole-crop wheat, brewers grains, fodder beet or maize silage into diets based on grass silage. Anim. Sci. 61:491-496.

Playne, M. J. and P. McDonald. 1966. The buffering constituents of herbage and of silage. J. Sci. Food Agric.17:264-268.

Rohweder, D. A., R. F. Barnes, and N. Jorgensen. 1978. Proposed hay grading standards based on laboratory analyses for evaluating quality. J. Anim. Sci. 47:747-759.

Spoelstra, S. F. 1983. Inhibition of clostridial growth by nitrate during the early phase of silage fermentation. J. Sci. Food Agric.34:145-152.

Sidhu, P. K., G. K. Bedi, Meenakshi, V. Mahajan, S. Sharma, K. S. Sandhuand, and M. P. Gupta. 2011. Evaluation of factors contributing to excessive nitrate accumulation in fodder crops leading to ill-health in dairy animals. Toxicol. Int. 18:22-26.

Succi, G., G. M. Crovetto, A. Tamburini, L. Rapetti, and G. Galassi. 1993. Determination of the net energy of wheat silage cut at the dough maturity stage of grain. In: Proceedings of 47th National Meeting of the Italian Veterinary Sciences. Milan, Italy. pp.1733-1737.

Tilley, J. M. A. and R. A. Terry. 1963. A two-stage technique for the in vitro digestion of forage crops. Grass Forage Sci. 
18:104-111

Van Soest, P. J., J. B. Robertson, and B. A. Lewis. 1991. Methods for dietary fiber, neutral detergent fiber, and nonstarch polysaccharides in relation to animal nutrition. J. Dairy Sci. 74:3583-3597.
Weinberg, Z. G., A. Bar-Tal, Y. Chen, M. Gamburg, S. Brener, L. Dvash, T. Markovitz, and S. Landau. 2007. The effects of irrigation and nitrogen fertilization on the ensiling of safflower (Carthamus tinctorius). Anim. Feed Sci. Technol. 134:152-161. Weinberg, Z. G., Y. Chen, and R. Solomon. 2009. The quality of commercial wheat silages in Israel. J. Dairy Sci. 92:638-644. 